\title{
GÊNESE DA INTELECTUALIDADE NEOLIBERAL SEGUNDO MICHEL FOUCAULT*
}

\section{GENESIS OF NEOLIBERAL INTELLECTUALITY ACCORDING TO MICHEL FOUCAULT}

Lucas Trindade da Silva*

\section{Introdução}

Inteligencja, intelligentsia e intellectuels são exemplos de palavras com uma origem terminológica e histórica essencialmente política.

No contexto polonês (inteligencja) e russo (intelligentsia), a partir da década de 40 e durante toda a segunda metade do século XIX, tais termos associavam-se à representação de uma "elite que se definia pelo grau de formação e de competência para tratar com o conhecimento erudito e com a cultura em geral, em contraste com as elites de sangue ou de posição econômica”, assim como "à ideia de grupo que, gozando de capacidades superiores de análise e de elaboração de propostas sociais, se constituía como protagonista político privilegiado", em defesa de "reformas sociais" e colocando-se no lugar "de guia do povo e de grupo portador da consciência nacional" (VIEIRA, 2008, p. 69).

Seus críticos no contexto russo concebiam a intelligentsia seja como um estrato verborragicamente elevado, porém incapaz de ação concreta, eficaz, na transformação social (Vieira cita o sarcasmo das Notas do Subsolo contra os representantes do belo e do sublime), seja como uma camada culta

\footnotetext{
* 0 presente trabalho foi realizado com apoio da Coordenação de Aperfeiçoamento de Pessoal de Nivel Superior - Brasil (CAPES) - Código de Financiamento 001. Este artigo utiliza e desenvolve a última seção da segunda parte da minha tese de doutorado, Biopolítica e o Enunciado da Autonomização das Esferas Sociais (ver SILVA, 2018), seguindo a inquietação especifica relativa à possibilidade de falarmos de uma intelectualidade neoliberal a partir das investigações de Michel Foucault (2008b). Agradeço as excelentes contribuições dadas pelos (as) pareceristas anônimos (as).

** Atualmente é bolsista PNPD/CAPES no PPGS da Universidade Federal de Pelotas - UFPel - (Pelotas/RS/Brasil). Doutor em Sociologia pela UnB. E-mail: lucastrindadedasilva@yahoo.com.br.
} 
que deveria tomar posição definida em relação ao desenvolvimento e explicitação da luta de classes na Rússia que fazia a passagem para o século XX. Ora "representante do ethos da renovação, da modernidade, da civilidade, do progresso do povo e da nação", ora "portadora de um espírito de soberba, sectário, eslavófilo e, portanto, incapaz de representar interesses universais e racionais" (VIEIRA, 2008, p. 70). Em todos os casos, a sua apreciação aparece em função de sua relação com a política.

Segundo Luciano Martins (1987) ${ }^{1}$, é do seu "isolamento social" que derivam as principais características da intelligentsia russa: “a) o conteúdo utópico de seu pensamento"; "b) a autoatribuição da liderança moral da nação e/ou representação dos direitos de camadas sociais politicamente afônicas"; “c) uma visibilidade devida mais à posição única de seus membros do que propriamente à sua constituição em stratum social, condição esta, aliás, incompatível com seu número excessivamente restrito"; "d)... seu sentimento de impotência, que só é suplantado por um ato de vontade: pelo sentimento de missão, de fundamento ético"; e) uma última característica relaciona o “"vazio social' no qual a intelligentsia se constitui" e sua atitude ambivalente "em face do papel do Estado no processo de mudança social".

Quando o neologismo intellectuel aparece em 1898 na letra de Clemenceau e é popularizado na crônica de Barrès, na esteira dos acontecimentos do Affaire Dreyfus (a condenação injusta e explicitamente antis- semita, em 1894, do oficial francês Alfred Dreyfus por supostamente realizar serviços de espionagem para a Alemanha), o termo continua a designar, de forma ainda mais precisa, "a existência de um protagonista político" (VIEIRA, 2008, p. 70). Aqui, os intelectuais são os dreyfusards, "a ação pública de artistas, intelectuais, cientistas e escritores”, entre eles Zola, Mirabeau, Proust, Durkheim, Poincaré, Anatole France, em favor de Dreyfus e contra o Estado francês. "Nesse contexto, os intelectuais foram, por um lado, entendidos como defensores intransigentes da liberdade e da justiça e, por outro, como traidores da pátria e da nação" (VIEIRA, 2008, p 71).

Mais uma vez encontramos um grupo sociologicamente difuso, amorfo em termos de classe, estrato social e interesse nacional, que se identifica sobretudo por seu domínio de bens simbólicos e por certa posição política progressista (com toda a heterogeneidade admissivel pelo adjetivo) que o faz colidir com o poder político oficial. "Sendo assim", escreve Vieira (2008, p. 71), "poderíamos afirmar que: enquanto as palavras sábio, erudito, letrado, culto representavam adjetivos associados a sujeitos privados”, intelligentsia e les intellectuels ganham "um sentido que relaciona de forma estreita as duas palavras à esfera política, à atividade cívica e à crítica do poder instituído"; "representam substantivos que nomeiam um sujeito político coletivo". É óbvio, continua Vieira (2008, p. 71-2), que Cícero, Maquiavel, Voltaire assumiam tal posição pública em outros contextos histó-

1. Texto sem paginação disponivel no site da ANPOCS: http://www.anpocs.org.br/portal/publicacoes/ rbcs $00 \quad 04 /$ rbcs04 $06 . h$ htm 
ricos, de modo que "a intervenção dos cultos na cena pública não é uma inovação do século XX”, mas “as condições materiais de organização da cultura nesse período, particularmente favorecida pela presença de jornais e de revistas de ampla circulação, propiciaram a formação da identidade dos intelectuais como protagonistas políticos”.

Do termo ao conceito de intelectual, passa-se, durante o século XX, de uma representação social a princípio generosa "sobre os ilustrados" para uma "desconstrução das representações e das autorrepresentações" (VIEIRA, 2008, p. 74) daquilo que agora é tomado como objeto de investigação. Mantém-se, no entanto, se tomarmos as abordagens já clássicas de Mannheim, Gramsci, Bourdieu, uma base claramente normativa de apreciação do conceito.

É plausível afirmar que Mannheim (2001) transforma em virtude aquilo que os críticos da intelligentsia concebiam como defeito: o caráter desenraizado, o "vazio" social a partir do qual emergem. Seria precisamente esse caráter desvinculado que permitiria à intelligentsia ser um fator central no planejamento democrático, na medida em que possibilitaria tanto uma compreensão aprofundada das diferentes visões de mundo em disputa numa situação dada, reunindo "as condições racionais para localizar historicamente e socialmente os condicionantes que originam as formas de pensar antagônicas” (VIEIRA, 2008, p. 75), como uma ação de síntese desinteressada e universalista destas diversas visões ou perspectivas.

Ao contrário de conceber a intelligentsia como desvinculada da política, Mannheim (2001) a pensa como forma por excelência de realização de uma política não-particularista e capaz de contemplar a pluralidade de valores definidores das sociedades modernas.
Em Gramsci (1968), como se sabe, há um significativo alargamento da noção de intelectual. Ao afırmar que "todos os indivíduos são intelectuais, embora nem todos exerçam a função de intelectuais”, Gramsci pretende: por um lado, “combater certo aristocratismo educacional e intelectual, como se as atividades intelectuais fossem privilégio natural de alguns poucos"; por outro, "indicar as possibilidades para a formação de intelectuais de um novo tipo oriundos da classe trabalhadora" (PASSIANI, 2018, p. 24-5).

0 conceito é utilizado em pelo menos "três sentidos principais" na obra gramsciana:

o intelectual tradicional, que despreza o sentimento popular e organiza-se como casta; o orgânico ao projeto do Estado burguês, que produz as condições ideológicas para a exploração dos trabalhadores pelo capitalismo; e o intelectual orgânico aos interesses das classes subalternas, que visa a organização de uma nova forma de domínio e de direção política (VIEIRA, 2008, p. 77).

Assim, como frisa Vieira (2008, p. 78), Gramsci realiza uma "dessacralização do intelectual como agente político”. Se a intelectualidade, mesmo quando pretensamente autônoma e neutra, define sempre uma tomada de posição em relação aos antagonismos sociais, tal política intelectual não se encontra mais vinculada exclusivamente ao polo progressista (entre reformista e radical) das camadas cultas e opositor a medidas estatais autocráticas e reacionárias. Também há uma intelectualidade que se define pelo interesse central em reproduzir e defender não só o Estado, mas relações sociais hierárquicas e formas diversas de dominação.

Tal dimensão política constitutiva tanto 
do termo como do conceito de intelectualidade nos leva a pensar qual contribuição Michel Foucault - que propõe tanto uma nova analítica do poder como um método genealógico de abordagem de práticas e discursos sócio-historicamente situados poderia dar a esse debate. 0 propósito deste artigo é, entretanto, mais modesto: trata-se de ler o curso Nascimento da Biopolítica, em diálogo com o instrumental conceitual rapidamente sumarizado acima, como uma investigação da gênese da intelectualidade ordoliberal e neoliberal. Assim, buscarei fundamentalmente pensar em que medida os discursos e práticas ordo e neoliberais analisados por Foucault definem uma intelectualidade e, de forma colateral, refletir sobre as contribuições específicas de Foucault para pensar a noção de intelectualidade.

\section{Governamentalidade liberal como regi- me de verdade}

Antes de adentrarmos a análise da gênese e desenvolvimento de uma intelectualidade neoliberal em Nascimento da Biopolítica, é necessário, sumariamente, delimitar o contraste decisivo entre, por um lado, a razão de Estado como regime de governo que se identifica ao Estado, por tê-lo como seu fim, e, por outro lado, a governamentalidade liberal, racionalidade de governo que simultaneamente transcende e incorpora o Estado, baseada não em critérios soberanos ou de justiça, mas em critérios veridicionais ou de verdade.

Para Foucault, é precisamente contra uma concepção ilimitada e totalizante da organização (policial) do Estado que se insurge, no desenrolar do século XVIII, uma nova racionalização da prática de governo, a governamentalidade. Não se trata mais de um Estado que deve regulamentar a vida social em seus mais ínfimos detalhes, mas de racionalizar o que o governo deve ou não fazer, distinguir quando sua ação é escassa, medida ou excessiva. Não mais o problema de "onde estão os direitos fundamentais e como os direitos fundamentais dividem o domínio da governamentalidade possível e o domínio da liberdade" (FOUCAULT, 2008b, p. 16) - a luta exterior entre polícia e direito -, mas de estabelecer um critério que demarque até onde deve ir o governo, do próprio governo pensando os seus limites. Tal critério é estabelecido pelo complexo saber-poder denominado economia política.

Se o direito aparecia como um princípio de limitação externo à razão de Estado, aqui é a economia política que emerge como princípio interno de autolimitação da prática de governo, pelas seguintes razões apontadas por Foucault (2008b, p. 19-23):

Primeiramente, não é por meio do direito que a economia política "interroga" sobre a legitimidade das "práticas governamentais"; não encara tais práticas "sob o prisma da sua origem, mas sob os seus efeitos". Em vez de se perguntar "o que é que autoriza um soberano a cobrar impostos? ", se pergunta: "quando se cobra um imposto, quando se cobra esse imposto nesse momento dado, de tal categoria de pessoas ou de tal categoria de mercadorias, o que vai acontecer?".

Em segundo lugar, a economia política critica a regulamentação policial da razão de Estado não a partir das liberdades garantidas pelo direito natural, mas pela defesa da "naturalidade" intrínseca à dinâmica populacional, que deve servir de parâmetro para a prática de governo. Os economistas concebem como "uma lei de natureza” o deslocamento da população "para os 
salários mais elevados", como "é uma lei de natureza a de que uma tarifa aduaneira protetora dos altos preços dos meios de subsistência acarreta fatalmente algo como a escassez alimentar".

Não obedecer a essa dinâmica natural da população - este é o terceiro e último ponto relevante - levaria ao fracasso de um governo. Não se trata mais do par "legitimidade/ilegitimidade", mas do par sucesso/ fracasso como critério da governamentalidade: "o maior mal de um governo, o que faz que ele seja ruim, não é o príncipe ser ruim, é ele ser ignorante".

Por trás do sucesso ou fracasso do governo está a capacidade do Estado discernir quando deve e quando não deve governar, de levar em conta o "princípio do máximo/ mínimo na arte de governar", substituto daquela "noção do equilíbrio equitativo, da 'justiça equitativa' que ordenava outrora a sabedoria do príncipe" (FOUCAULT, 2008b, p. 24). Com a economia política, portanto, emerge um "regime de verdade" (FOUCAULT, 2008b, p. 25, itálico nosso) relativo à prática de governo, que as julga "como boas ou ruins não em função de uma lei ou de um princípio moral, mas em função de proposições que serão, elas próprias, submetidas à demarcação do verdadeiro e do falso" (FOUCAULT, 2008b, p. 25-6)².

Esse liberalismo, essa razão de Estado mínimo, que se desenvolve a partir do século XVIII, é rigorosamente um naturalismo. É a partir do enquadramento da população/ mercado como uma natureza, regida pela lei do interesse, que se deriva uma concepção do governo do Estado e das relações interestatais. 0 uso da palavra liberal se justifica, para Foucault, pelo fato de que esta nova prática governamental "implica em seu cerne uma relação de produção/ destruição [com a] liberdade [...] É necessário, de um lado, produzir a liberdade, mas esse gesto mesmo implica que, de outro lado, se estabeleçam limitações, controles, coerções, obrigações apoiadas em ameaças, etc." (FOUCAULT, 2008b, p. 87).

$\mathrm{Na}$ medida em que é um pretenso interesse da população que deve orientar a prática de governo, e que esse interesse é passível de ser determinado cientificamente, a função do governo é duplamente definida: por um lado, deve se retirar quando esse interesse está se realizando, por outro, deve intervir contra aquilo que constitui "um perigo para o interesse de todos". As “estratégias de segurança”, assim, emergem como "o inverso e a própria condição do liberalismo” (FOUCAULT, 2008b, p. 89) 3 .

Com a economia política e a governamentalidade liberal, a relação saber-poder também ganha uma nova configuração. Não se trata mais do Estado produzindo o saber para

2. Como escrevem Bröckling, Krassman e Lemke (2011, p. 12), os estudos da governamentalidade "abrem um campo político-epistemológico que Foucault define como 'política da verdade'”.

3. "The rationality of security is, in Foucault's rendering, as inherently open-ended one: it deals not just in closed circuits of control, but in calculations of the possible and the probable. The relation of government with which it corresponds is not solely a functional, but also a 'transactional' one: it structures government as a practice of problematization, a zone of (partially) open interplay between the exercise of power and everything that escapes its grip" (GORDON, 1991, p. 35-6). 
a sua própria atuação como no Estado policial (onde a estatística era interna ao corpo administrativo), trata-se agora de uma ciência exterior à arte de governar, "uma cientificidade que vai cada vez mais reivindicar sua pureza teórica, que vai ser a economia; e, depois, que vai reivindicar ao mesmo tempo o direito de ser levada em consideração por um governo que terá de modelar por ela suas relações" (FOUCAULT, 2008a, p. 474-5) ${ }^{4}$.

Temos aqui um elemento importante a ser enfatizado antes de enfim lermos a análise foucauldiana da governamentalidade neoliberal. É plausível afirmar que, nesse momento da sua obra, delimitado não só pelo interesse genealógico, mas por uma genealogia das artes ou racionalidades de governo, a expressão intelectual que interessa a Foucault não diz respeito ao âmbito literário ou artístico, mas da emergência de um saber que se pretende científico e verdadeiro sobre a população e que, amparado na verdade, reivindica a sua influência na política e no Estado. Tal intelectualidade se singulariza por propor uma arte de governar as coisas e os seres humanos não pelo fim de preservar e expandir o próprio Estado, não por critérios jurídicos ou de justiça, mas pela dinâmica intrínseca, natural, pela verdade desses próprios seres e coisas. Embora a governamentalidade neoliberal enuncie uma verdade fundamentalmente distinta da economia po- lítica clássica/liberalismo, ambas pretendem ser uma arte de governo fundada numa verdade. Eis o que particulariza, para Foucault, a moderna relação entre saber e poder e uma certa forma de intelectualidade moderna.

\section{A emergência de um liberalismo renovado}

No século XX, a instalação de "mecanismos de intervenção econômica” de perfil keynesiano passou a ser justificado não pela crítica ao Estado policial mercantilista, mas “para evitar esse 'a menos' de liberdade que seria acarretado pela passagem ao socialismo, ao fascismo, ao nacional-socialismo" (FOUCAULT, 2008b, p. 94). Tais intervenções já exprimem uma crise da governamentalidade liberal, na medida em que questiona discursiva e praticamente o postulado da autorregulamentação do mercado, que se respeitado teria como resultado a realização do interesse coletivo.

É contra o socialismo, o fascismo, o nacional-socialismo, a partir dessas novas experiências históricas que se formula um novo discurso liberal ou um liberalismo tardio, o que permite a Foucault (2008b, p. 107) realizar um pulo para a atualidade e perguntar: "Como se apresenta a programação liberal ou, como se diz, neoliberal na nossa época?”

São duas, para ele (FOUCAULT, 2008b, p. 107-8), as principais vertentes que bus-

4."Foucault sees Adam Smith's The Wealth of Nations as effecting not only a transformation in political and economic thinking but also a transformation in the relationship between knowledge and government. For Cameralist thinkers, police science and state action are isomorphous and inseparable; the notion of 'science' carries here an immediately pragmatic connotation, akin, as Foucault puts it, to the calculating know-how of diplomacy. For political economy, on the other hand, scientific objectivity depends on the maintenance of relative distance and autonomy from the standpoint and preoccupations of state, while the content of economic science affirms the necessary finitude and frailty of the state considered as knowing subject" (GORDON, 1991, p. 14-5). 
cam construir um novo liberalismo: 1) a “ancoragem alemã”, que se constitui através de uma reflexão sobre as experiências da República de Weimar, da crise de 1929, do nazismo e da reconstrução pós-guerra; 2) e a "ancoragem americana”, que se desenvolve sobretudo pós-1945, reflete o New Deal, reage contra Roosevelt e os intervencionismos representados nas figuras de Truman, Kennedy e Johnson. Como pontos comuns, as duas ancoragens: são críticas a todo intervencionismo econômico que desequilibre o mecanismo da concorrência; têm repulsa a tudo que se delineie como planejamento, intervenção, direção; têm como referências comuns o "neomarginalismo austríaco", de onde saem Von Mises e Hayek, por exemplo.

Ambas definem - eis um primeiro ponto a ser salientado a partir do nosso problema - aquele isolamento fundamental da intelligentsia salientado por Martins (1987). Isolamento não só estrutural, mas, sobretudo, normativo: trata-se da missão de construir uma concepção neoliberal de sociedade, cientificamente fundamentada (sobretudo economistas), como uma ilha rodeada por um oceano majoritário de concepções intervencionistas.

Exemplo desta autoconcepção de isolamento é a afirmação de Hayek (2010, p. 32) no prefácio de 1976 à edição inglesa d'O ca- minho da servidão, de que, para o seu "problema, pouco importa o fato de alguns desejarem menor grau de socialismo do que outros, de que estes queiram o socialismo em função do interesse de um grupo e aqueles, no interesse de outro", o que importa "é que, se considerarmos as pessoas cujas opiniões influem nos acontecimentos neste país, todas elas são em certa medida socialistas".

Foucault (2008b, p. 108) se debruça, primeiramente, sobre a "ancoragem alemã" emergente na Europa pós-guerra, contexto de elaboração de "políticas econômicas comandadas por uma série de exigências" de reconstrução: 1) "reconversão de uma economia de guerra numa economia de paz" a partir da "integração" de "novos dados demográficos” e geopolíticos; 2) "planificação como principal instrumento dessa reconstrução”, enquadrada pelo peso do plano Marshall, "que implicava na prática salvo, precisamente, os casos da Alemanha e da Bélgica... - uma planificação de cada país e certa coordenação dos diferentes planos"; 3) atendimento a "objetivos sociais que foram considerados politicamente indispensáveis para evitar que se repetisse o que acabava de acontecer, a saber, o fascismo e o nazismo na Europa, exigências que foram formuladas na França pelo CNR", o Conselho Nacional de Resistência ${ }^{5}$.

5. "O Conselho Nacional de Resistência (CNR) havia sido constituído na primavera de 1943 para unificar os diversos movimentos de Resistência, politicamente divididos. Foi presidido por Jean Moulin, depois por Georges Bidault. 'Todos, em sua reunião plenária de 15 de março de 1944, se puseram de acordo para permanecer unidos depois da Libertação. A Carta da Resistência, que resultou dessas deliberações, discutida e aprovada pelos diversos agrupamentos que compunham o CNR, continha um programa social e econômico ousado. Entre outras reformas, ela reclamava 'um plano completo de seguridade social, visando assegurar a todos os cidadãos os meios de existência, no caso em que sejam incapazes de obtê-los pelo trabalho, com gestão por parte dos representantes dos interessados e do Estado' (H. G. Galant, Histoire politique de la sécurité sociale française, 1945-1952...)" (FOUCAULT, 2008b, p. 131-2, nota 15). 
Vibra, repetimos, um ideário generalizado que preconiza o intervencionismo estatal na economia como meio para a reconstrução da Europa recém-saída da Guerra. É nesse contexto que se forma, em 1947, "junto da administração alemã da economia”, situado na "zona anglo-americana”, o Conselho Científico (FOUCAULT, 2008b, p. 109). Conselho este "composto metade por representantes da Escola de Friburgo (W. Eucken, F. Böhm, A. Müller-Armack, L. Miksch, A. Lampe, 0. Veit...), metade por representantes da doutrina cristã-social, como o jesuíta 0. von Nell-Breuning, e socialista, como K. Schiller, G. Weisser, H. Peter" (FOUCAULT, 2008b, p. 132, nota 16).

Em 18 de abril de 1948, tal Conselho apresenta um relatório que gira em torno do "seguinte princípio", citado por Foucault (2008b, p. 109), aceito posteriormente "por unanimidade”: “'0 Conselho é de opinião que a função de direção do processo econômico deve ser assegurada o mais amplamente possível pelos mecanismos dos preços"”. Deriva daí a exigência de "liberação imediata dos preços a fim [de se aproximarem dos] preços mundiais”, exigência simétrica àquela feita pelos fisiocratas em polêmica com os mercantilistas. Em 28 de abril de 1948, Ludwig Erhard - membro do conselho, dirigente administrativo da zona anglo-americana, futuro "ministro da economia de Adenauer" e "considerado o pai do "milagre econômico (Wirtschaftswunder) alemão" (FOUCAULT, 2008b, p. 132, nota 19), futuro chanceler da Alemanha -, realiza em Frankfurt um discurso baseado naquele relatório.

Foucault (2008b, p. 114) destaca, na análise desse discurso, a ideia de que é a "economia" a produtora da "legitimidade" do Estado que, por sua vez, é "avalista” da economia. Tal como no liberalismo clássico, "a economia é criadora de direito público". "Gênese, genealogia permanente do Estado a partir da instituição econômica”. Destaca também a ligação estabelecida entre liberação da ação no mercado - deixar agir - e liberdade de expressão - deixar falar, falar sobretudo "que está certo deixá-las agir" -, de modo que "a adesão a esse sistema liberal produz... além da legitimação jurídica”, “o consenso permanente” (FOUCAULT, 2008b, p. 115).

Baseado nessa análise, Foucault (2008b, p. 117) usa a expressão "Estado econômico" para caracterizar o grau de imbricamento entre a economia e a política no discurso neoliberal alemão. Discurso, por sua vez, fundamental na orientação da política econômica alemã a partir de 1948: em 24 de junho de 1948, pouco menos de dois meses após a palestra de Erhard em Frankfurt, há a "liberação dos preços industriais, depois dos preços dos alimentos, liberação progressiva de todos os preços”, embora lentamente; em 1952, "liberação dos preços do carvão e da eletricidade"; em 1953, "agora para o comércio exterior, há uma liberação das trocas que atinge um percentual de mais ou menos 80 [\%], 95\%", de modo que “em [19]52-53, a liberação está mais ou menos consolidada" (FOUCAULT, 2008b, p. 117-8).

Junto à crescente liberação da economia, cresce também a adesão ao programa neoliberal. Primeiro da Democracia Cristã, da qual fazia parte o próprio Erhard. Depois dos sindicatos, com seu símbolo maior na adesão de "Theodor Blank, vice-presidente do sindicato dos mineiros”, e sua declaração de "que a ordem liberal constitui uma alternativa válida ao capitalismo e ao socialismo". Por fim, "adesão da social-democracia” que, em 1959, no congresso de Bad Godesberg, "renuncia ao princípio da passagem à socialização dos meios de pro- 
dução", "reconhece que a propriedade privada dos meios de produção, não apenas é perfeitamente legítima, como tem direito à proteção e ao incentivo do Estado", e "aprova o princípio de uma economia de mercado... onde quer que "reinem as condições de uma verdadeira concorrência” (FOUCAULT, 2008b, p 118-20).

É num aprofundamento dos temas desenvolvidos a partir do discurso dado por Ludwig Erhard em 24 de junho de 1948 que Foucault (2008b, p. 141) então empreende uma análise da Escola de Friburgo, que constitui a reserva de saber em torno de Erhard, sobretudo Walter Eucken, membro daquele Conselho Científico que já mencionamos e "professor de economia em Friburgo" desde 1927, onde "travou conhecimento com Husserl” e a fenomenologia.

Em 1936, Eucken "funda uma revista que se chama Ordo", é ao redor dessa revista que se forma a "escola de economistas chamada Escola de Friburgo ou, ainda, os 'ordoliberais'” (FOUCAULT, 2008b, p. 1412), formada por outros membros daquele Conselho Científico, como Franz Böhm, Müller-Armack, e outros que não fizeram parte do Conselho, como Rüstow e Hayek. Esse último vem da escola austríaca, passa, em seu exílio, por Inglaterra, depois Estados Unidos - é "um dos inspiradores do liberalismo americano contemporâneo, ou do anarcocapitalismo" - e retorna para a Alemanha em 1962, "sendo nomeado professor em Friburgo” (FOUCAULT, 2008b, p. 143). Tais são os principais nomes levantados na análise foucauldiana.

Três objetivos comuns que, para Foucault (2008b, p. 146), permitem pensar a colaboração entre estes autores como uma Escola: 1) "fundar a legitimidade de um Estado a partir de um espaço de liberdade dos parceiros econômicos"; 2) definir o "sistema geral" que poderia se opor a esse objetivo, "o conjunto que vai do obstáculo ao inimigo e constitui, grosso modo, o campo de adversidade com o qual teriam de se haver"; 3) definir a distribuição e redistribuição dos "recursos conceituais e técnicos que eles tinham à... disposição" para assim driblar as adversidades.

Se o programa do Conselho Científico e de Erhard tem ampla aceitação na década de 1950, antes disso, escreve Foucault (2008b, p. 147-9), a história das doutrinas e políticas econômicas na Alemanha se mostrava fundamentalmente contrária ao ideário liberal: 1) desde Friedrich List, que sistematizou a posição protecionista na década de 1840, formula-se uma tendência de identificação do liberalismo ao imperialismo inglês; 2) a política econômica bismarckiana também era expressamente antiliberal; 3) com a primeira guerra até 1933 instaura-se uma economia de guerra planificada; 4) a partir de 1925 até 1930, o keynesianismo exerce forte influência sobre economistas e políticos alemães.

A tomada de poder pelo nacional-socialismo não significa, para os ordoliberais, uma ruptura com esse histórico antiliberal. Pelo contrário, para eles o "que o nazismo fez foi pôr em estrita coalescência esses diferentes elementos, ou seja, a organização de um sistema econômico em que a economia protegida, a economia de assistência, a economia planificada, a economia keynesiana formavam um todo" (FOUCAULT, 2008b, p. 148). A “administração econômica implantada" pelo nazismo forma aquele "sistema geral" ou "campo de adversidade" coerente e integrado contra o qual se insurgem os ordoliberais.

Os ordoliberais estabelecem uma relação necessária entre intervencionismo estatal e autoritarismo. Criam a oposição inescapá- 
vel entre política liberal e política antiliberal, esta obrigatoriamente autocrática. Identificam o campo de adversidades contra o qual o seu isolamento crítico se posiciona em postura negativa - "desfazer-nos de todos os elementos da herança socialista que representam um perigo para a sociedade livre" (HAYEK, 2010, p. 23) -, base para a formulação de suas proposições utópicas sobre a economia de mercado. Desse modo, conseguiram retoricamente persuadir, trazer para o seu projeto, o contingente de uma Alemanha arrasada pela Guerra e com a enorme ferida aberta da experiência nacional-socialista.

Nessa altura da discussão que Foucault (2008b, p.158-9) avança na distinção entre o ordoliberalismo e o liberalismo clássico, pois, para o último, ao conceber uma concepção naturalista da população e do mercado, buscava-se estabelecer um "limite" para a ação estatal e um "domínio" que deveria ser mantido livre da mesma. Para os ordoliberais, por sua vez, dada a essência perversa intrínseca ao Estado, pretensamente provada pela experiência histórica, e dada a ausência destes "defeitos" intrínsecos no caso da "economia de mercado", não se trata de pedir a liberdade da última, nem que ela seja meramente "o princípio de limitação do Estado", mas de conceber a "economia de mercado" como "o princípio interno de regulação do Estado, de ponta a ponta da sua existência e da sua ação”. Enquanto o liberalismo clássico defendia a "liberdade de mercado definida pelo Estado e mantida de certo modo sob vigilância estatal”, os ordoliberais defendem "a liberdade de mercado como princípio organizador e regulador do Estado, desde o início da sua existência até a última hora das suas intervenções”, "um Estado sob a vigilância do mercado em vez de um mercado sob a vigilância do Estado”.

Eis, para Foucault (2008b, p. 160), a singularidade do novo liberalismo, "quer se tome a forma alemã..., quer se tome a forma americana do anarcoliberalismo": não mais a defınição dos limites do que deve ser o livre mercado, do que deve ser a ação governamental e de como o Estado pode garantir o livre mercado, mas "uma formalização geral dos poderes do Estado e da organização da sociedade a partir de uma economia de mercado"6.

Outra diferença fundamental entre liberalismo e neoliberalismo salientada por Foucault (2008b) e rapidamente levantada na aula de 7 de fevereiro de 1979, diz respeito à própria definição do mercado no novo liberalismo.

Vimos como o liberalismo clássico concebe o mercado como uma natureza, que

6 “...esta concepción no pretende en absoluto disponer un espacio específico y propio para el mercado, que coexista además con otras racionalidades y sobre todo con la razón de Estado. Al contrario, aquí se trata de difundir el mercado por todas partes. Los mecanismos competitivos no deben quedar circunscriptos a ciertos sectores. Deben extenderse a toda la sociedad; deben cumplir su papel regulador lo más ampliamente posible, en la mayor cantidad de sectores del mundo social. La utopía neoliberal es incorporar el máximo de realidades a un entramado mercantil" (LAGASNERIE, 2015, p. 36). Da mesma forma Brown (2015, p. 17), seguindo Foucault, define o neoliberalismo como "uma forma peculiar de razão que configura todos os aspectos da existência em termos econômicos”. 
tem sua lei na dinâmica espontânea das trocas comerciais, através das quais se realiza o interesse tanto dos indivíduos como da população, o núcleo teórico da defesa do laissez-faire. 0 novo liberalismo, por sua vez, não considera as trocas no mercado, ou melhor, a concorrência como uma natureza, mas como uma essência, um eîdos no sentido da fenomenologia husserliana. Foucault (2008b, p. 163-4) nos esclarece que "assim como para Husserl uma estrutura formal não se oferece à intuição sem um certo número de condições, assim também a concorrência como lógica econômica essencial só aparecerá e só produzirá seus efeitos sob certo número de condições cuidadosa e artificialmente preparadas". A concorrência é o objetivo e resultado da governamentalidade, o governo não vem depois, como no liberalismo clássico, para eliminar aquilo que é nocivo à concorrência, mas se apresenta do começo ao fim do processo como promotor da concorrência, como aquilo que dá condições para o livre mercado, ponto que constitui o núcleo teórico da defesa ordoliberal de que é "necessário governar para o mercado, em vez de governar por causa do mercado" (FOUCAULT, 2008b, p. 165) ${ }^{7}$.

Tais diferenças tornam explícito o $\mathrm{ca}$ ráter utópico do projeto ordo e neoliberal. Seu projeto de sociedade define um telos a ser atingido que, para sê-lo, necessita da convergência de inúmeras forças. É a imagem futura de uma economia de mercado perfeita, tomada como a melhor forma de organização social, garantidora das liber- dades individuais, que funciona como referente para a constituição de um projeto político no presente.

A economia política e o liberalismo clássico, por sua vez, não podem ser pensados como uma utopia nesse mesmo sentido. Afinal, se o livre mercado é uma natureza já dada, da qual o Estado deveria se retirar ou apenas garantir a sua liberdade de movimento, trata-se não de um futuro, mas de um dado existente.

"A liberdade de mercado necessita de uma política ativa e extremamente vigilante" (FOUCAULT, 2008b, p. 183): princípio geral enunciado por Röpke em seu Gesellschaftskrisis e compartilhado entre os membros da Comissão Internacional de Estudo para a Renovação do Liberalismo, formada a partir do Colóquio Walter Lippmann, realizado em 1938. Encontro este fortemente marcado pela influência das ideias ordoliberais e momento crucial da articulação de uma rede intelectual neoliberal de caráter internacional, transcendendo os limites ainda estreitos da Escola de Friburgo e da revista Ordo.

Não se trata mais, portanto, escreve Foucault (2008b, p. 184), da questão liberal clássica da "agenda/non agenda", de saber no que o Estado deve e não deve mexer, mas de "saber como mexer". Foucault nos oferece três exemplos de como os ordoliberais concebem a governamentalidade naquele sentido de uma politica ativa sem dirigismo.

Primeiro as medidas antimonopólio. Na tradição liberal, ou em certa tradição liberal, o monopólio é visto como consequência da

7. Para os neoliberais, escrevem Dardot e Laval (2016, p. 81), a “independência da economia com relação às instituições sociais e políticas é o erro básico da mística liberal que leva ao não reconhecimento do caráter construído do funcionamento do mercado". 
concorrência, de modo que a intervenção estatal deve barrar esse desenvolvimento. Para os neoliberais, inversamente, o monopólio é concebido como um “"corpo estranho no processo econômico” (expressão de Röpke em Gesellschaftskrisis citada por FOUCAULT, 2008b, p. 185) causado pelos mais diversos fatores extra-econômicos: pela intervenção pública na economia (concessão estatal arcaica de privilégios a certos grupos e famílias); por mecanismos jurídicos (herança, direito de sociedades por ação, patentes, etc.); por protecionismo alfandegário, etc. 0 ativismo sem estatismo é expresso, aqui, na necessidade, para os ordoliberais, de "estabelecer uma moldura institucional que terá a função de impedir que pessoas, tanto poderes individuais, quanto poderes públicos, intervenham para criar o monopólio" (FOUCAULT, 2008b, p. 189).

Segundo "a questão das ações conformes”, sintetizada em um texto de Eucken publicado em 1952 "que se chama Grundsätze der Wirtschaftspolitik (os fundamentos da política econômica)" (FOUCAULT, 2008b, p. 189), as ações conformes se dividem, para Eucken (FOUCAULT, 2008b, p. 189-91), em "ações reguladoras" e "ações ordenadoras". As primeiras têm "necessariamente como objetivo principal a estabilidade dos preços, a estabilidade dos preços não como uma fixidez, mas como o controle da inflação". Assim, ativismo em prol da estabilidade dos preços através do controle inflacionário mediante instrumentos como a "política de crédito", a "redução moderada" dos tributos, mas nunca pelo dirigismo planificador do "tabelamento dos preços", do "subsídio a um setor do mercado", do "investimento público" ou da política de pleno emprego.

As ações ordenadoras, por sua vez, "têm por função intervir nas condições do mercado, mas nas condições mais fundamentais, mais estruturais, mais gerais" (FOUCAULT, 2008b, p. 192) do que as ações reguladoras. São elas, precisamente, que fornecem as condições para a concorrência perfeita, a "moldura" para o correto transcorrer da dinâmica do mercado.

0 exemplo privilegiado por Foucault (2008b, p. 192-4), ao debruçar-se sobre a obra de Eucken supracitada, é o da agricultura alemã que, na visão do ordo, nunca foi de fato integrada "completamente, exaustivamente à economia de mercado". Dada essa relativa exterioridade da agricultura, não seria o caso de um ativismo, como nas ações reguladoras, visando a manter certas condições de reprodução da concorrência, mas de "modificar" as "bases materiais, culturais, técnicas, jurídicas”; de estabelecer a "moldura"; de criar as condições para a devida intervenção da economia de mercado. Condições que dizem respeito, no contexto específico da obra de 1952, à: diminuição da população através do estímulo à migração; "aperfeiçoamento das técnicas", disponibilizando "ferramentas", insumos e "formação" aos agricultores; modificação do "regime jurídico das terras, em particular com leis sobre a herança, com leis sobre o arrendamento das terras”, etc.; modificação do regime de "alocação dos solos, e a extensão, a natureza e a exploração dos solos disponíveis"; intervenção a partir dos recursos técnicos disponíveis no próprio clima.

Trata-se, em suma, nas ações ordenadoras, de criar ou de desenvolver a economia de mercado onde ela não existe ou existe de forma ainda parcial.

Terceiro, a política social, afirmada em claro contraste, mais uma vez, com uma postura dirigista e com um imaginário keynesiano de bem-estar. Antes de qualquer coisa, de modo algum, pensam os ordoliberais, a igualdade de condições sociais pode ser o ob- 
jetivo de uma política econômica, já que são exatamente as diferenças que constituem a boa dinâmica do mercado, da concorrência e o mecanismo dos preços. Uma política social, nesse novo liberalismo, deve, portanto, no máximo, buscar garantir "um mínimo vital” para aqueles, "de modo definitivo ou passageiro", incapazes de "assegurar sua própria existência”. Fundamental, entretanto, numa posição decididamente contrária a qualquer socialização planificada do consumo e da renda, deve ser uma política social que tenha como "instrumento" por excelência “a capitalização mais generalizada possível para todas as classes sociais" mediante a propriedade privada. A "política social verdadeira e fundamental” é, enfim, o "crescimento econômico” (FOUCAULT, 2008b, p. 196-8).

Foucault (2008b, p. 198-9) chama isto de "política social privatizada”, que consiste na "ideia de uma privatização dos mecanismos de seguro, em todo caso a ideia de que cabe ao indivíduo, pelo conjunto das reservas que ele vai poder dispor, seja a título simplesmente individual, seja por intermédio das sociedades de ajuda mútua, etc., [protegerse dos riscos]". Ideário que Foucault percebe não só no discurso ordoliberal alemão, não só na política econômica alemã do pós-guerra, mas também na França do seu tempo.

Vê-se claramente como a caracterização do ativismo político sem dirigismo ordoliberal não quer dizer menos governo, mas de pensar a possibilidade de menos Estado e mais "intervenção governamental”, "densa”, "frequente”, “ativa”, "contínua”. "Vai se tratar, portanto, não de um governo econômico, como aquele com que sonhavam os fisiocratas", que teria "apenas de reconhecer e observar as leis econômicas”, mas de "um governo da sociedade" (FOUCAULT, 2008b; 199). 0 "objeto da ação governamental é o que os alemães chamam de 'die soziale Umwelt', o ambiente social" (FOUCAULT, 2008b, p. 200).

Tal governo da sociedade, tal utopia, não tem como "princípio regulador" fundamental (também em contraste com o governo econômico do liberalismo clássico) “a troca de mercadorias", mas os "mecanismos da concorrência”; não "uma sociedade submetida ao efeito-mercadoria", mas "uma sociedade submetida à dinâmica concorrencial; não uma sociedade de supermercado, mas uma sociedade empresarial. 0 homo oeconomicus que se quer constituir não é o homem da troca, não é o homem consumidor, é o homem da empresa e da produção" (FOUCAULT, 2008b; 201).

Nessa ação governamental orientada para o soziale Umwelt, o principal objetivo, na leitura de Foucault (2008b, p. 203), é "generalizar, difundindo-as e multiplicando-as na medida do possível, as formas 'empresa' que não devem, justamente, ser concentradas na forma nem das grandes empresas de escala nacional ou internacional, nem tampouco das grandes empresas do tipo do Estado", mas de desenvolver a "forma "empresa' no interior do corpo social”, "de fazer do mercado, da concorrência e, por conseguinte, da empresa o que poderíamos chamar de poder enformador da sociedade".

Outro elemento necessário, segundo os ordoliberais, para alcançar esse tipo de formalização da sociedade, é a "redefınição da instituição jurídica e das regras do direito necessárias numa sociedade regulada a partir e em função da economia concorrencial de mercado; ou seja, grosso modo, o problema do direito" (FOUCAULT, 2008b, p. 222).

Novamente é o fato do mercado não ser concebido como uma natureza, mas como algo que só se revela essencialmente sob certas condições, a base para a abordagem da questão do direito na Gesellschaftspoli- 
tik ordoliberal. Louis Rougier sintetiza essa posição - Foucault retorna aos discursos do Colóquio Walter Lippmann - e por isso é amplamente citado. Para ele: o "'regime liberal não é apenas o resultado de uma ordem natural espontânea, como declaravam, no século XVIII, os numerosos autores dos Códigos da natureza; é também o resultado de uma ordem legal que supõe um intervencionismo jurídico do Estado”. Uma “"economia verdadeiramente liberal'”, continua Rougier citado por Foucault (2008b, p. 223-4), deve ser "submetida a uma dupla arbitragem: à arbitragem espontânea dos consumidores, que partilham os bens e os serviços que lhes são oferecidos no mercado ao sabor das suas conveniências, pelo plebiscito dos preços, e, [por outro lado], à arbitragem concertada do Estado, que assegura a liberdade, a lealdade e a eficiência do mercado".

0 jurídico é entendido, nessa visão amplamente compartilhada entre os ordoliberais, como aquilo que "enforma o econômico, econômico esse que não seria o que é sem o jurídico", de modo que, continua Foucault (2008b, p. 225-6), “deve-se falar de uma ordem econômico-jurídica”. Algo como uma esfera econômica separada, autônoma, portanto, não é algo "natural" anterior ao político e ao jurídico, mas resultado possível apenas por "abstração a posteriori, por abstração formalizante". A esse "conjunto econômico-jurídico", a esse "conjunto complexo" onde os "processos econômicos só existem realmente na história na medida em que uma moldura institucional e regras positivas lhe proporcionam suas condições de possibilidade", Eucken denomina "sistema".

Dentro do escopo do projeto ordoliberal, a figura da indissociabilidade histórica real entre os quadros político-institucionais e os processos econômicos busca demonstrar que o capitalismo nunca padeceu de con- tradições intrínsecas, insuperáveis. Assim, caso admitamos o raciocínio ordoliberal de que "não é do capitalismo decorrente $d a$ lógica do capital que se trata, mas de um capitalismo singular constituído por um conjunto econômico-institucional, então deve-se poder intervir nesse conjunto, e intervir para inventar outro capitalismo" (FOUCAULT, 2008b, p. 230).

Se os defeitos e distorções são imputados a influências jurídico-institucionais, não é através do "intervencionismo econômico" ("nenhum" ou "mínimo" na pregação ordoliberal) que tais defeitos e distorções serão sanados, mas com "o máximo de intervencionismo jurídico" (FOUCAULT, 2008b, p. 230). Deriva daí a defesa de “aplicar à economia algo que na tradição alemã se chama Rechtstaat e que os ingleses chamam de Rule of law" (FOUCAULT, 2008b, p. 231), o Estado de direito.

Expressão maior da governamentalidade moderna, o Estado de direito - nem despotismo soberano nem Estado policial administrativo - é defınido como o "Estado em que são distinguidas em seu princípio, em seus efeitos e em suas validades, as disposições legais, de um lado, expressão da soberania, e as medidas administrativas, de outro" (FOUCAULT, 2008b, p. 233), modalidade que exprime crescentemente, no decorrer do século XIX e XX, a forma de "um Estado em que cada cidadão tem possibilidades concretas, institucionalizadas e eficazes de recurso contra o poder público" (FOUCAULT, 2008b, p. 234). Em contraste com o direito (da população) como oposição à razão (policial) de Estado, o direito (as garantias de ação contra o abuso do poder estatal) como elemento interno, definidor do Estado.

Dado, como vimos, que as contradições do capitalismo não são intrínsecas à lógica do capital, mas se enraízam nos elementos 
político-jurídico-institucionais do amplo processo (econômico e extraeconômico) que caracteriza o "sistema”, e que tais males não devem ser, portanto, atacados através do intervencionismo econômico, mas de intervencionismo jurídico-institucional, os ordoliberais buscam na introdução dos "princípios gerais do Estado de direito na legislação econômica” um meio de "renovar o capitalismo" (FOUCAULT, 2008b, p. 235). E “aplicar o princípio do Estado de direito na ordem econômica" significa "grosso modo", escreve Foucault (2008b, 236), “que não poderá haver intervenções legais do Estado na ordem econômica a não ser que essas intervenções legais adquiram a forma, e adquiram somente a forma, da introdução de princípios formais. Não há outra legislação econômica senão formal”.

Foucault (2008b, p. 236-8) apresenta Hayek, Constituição da Liberdade, como quem "melhor defıniu o que se devia entender por essa aplicação dos princípios do Estado de direito ou do Rule of law na ordem econômica”, que também é mais um patamar na oposição a toda ideia de "planificação".

Um plano, em seus traços essenciais, é definido por Hayek: como o estabelecimento de fins econômicos rígidos e precisos; pela possibilidade de correção centralizada caso a realização do plano ou seus efeitos não estejam sendo devidamente alcançados; e pela centralidade do poder público como sujeito dominador/controlador, "sujeito universal", dos processos econômicos. Uma "legislação econômica formal”, por sua vez e inversa- mente: não tem fins explícitos; o Estado não aparece como o sujeito formulador e executor por excelência; uma regra formal (o que deve e o que não se deve fazer) não pode estar sujeita a correções autocráticas em seu processo de execução; deve ser uma moldura que confira liberdade aos agentes, e o Estado é só mais um agente entre outros.

A legislação formal funciona, nessa visão, como a "regra do jogo" econômico, como a moldura, e as regras de um jogo nunca devem interferir diretamente nas táticas e estratégias, conformes às regras formais, utilizadas pelos jogadores. A imagem depreciada da planificação é de uma ação centralizada, de uma onipresença, que interfere continuamente nas movimentações de sujeitos e coisas. Assim - Foucault (2008b, p. 238-9) sintetiza a análise -, um "capitalismo renovado", um novo "capitalismo econômico institucional, econômico-jurídico", que deve ser pensado como um “jogo de empresas no interior de uma moldura jurídico-institucional garantida pelo Estado”.

Consequência imediata dessa nova concepção de Estado inteiramente reelaborada a partir da afırmação da economia de mercado e do mecanismo da concorrência é a defesa de uma "desfuncionalização" crescente da "ação econômica que os planos traziam consigo", junto à "multiplicação da dinâmica de empresas e, com isso, necessidade de instâncias judiciárias ou, em todo caso, de instâncias de arbitragem cada vez mais numerosas”. E não se trata aqui de uma posição teórico-normativa unilateral de Hayek ${ }^{8}$.

8 As convergências entre Louis Rougier, F. Hayek e W. Röpke evidenciam a influência do ordoliberalismo no Colóquio Walter Lippmann. Além do seu trabalho na Escola de Fribugo e na própria revista Ordo, já mencionados, para a caracterização do Hayek dos anos 1930 e 1940 como um ordoliberal, ver Stefan Kolev (2010). 
Foucault (2008b, p. 241) cita diretamente W. Röpke que, em La crise de notre temps, defende "'fazer dos tribunais, muito mais do que no passado, órgãos da economia e confiar à sua decisão missões que até agora foram confiadas às autoridades administrativas"”. Quanto menos planificação, menor interferência administrativa, menor também a intervenção econômica; quanto maior a legislação formal da economia, multiplicação das instâncias judiciárias, maior, portanto, a liberdade dos agentes econômicos.

Mais uma vez a lógica do jogo: em caso de desrespeito às regras do jogo, não é a intervenção administrativa estatal que deve resolver os litígios e reorientar a dinâmica econômica; são os próprios agentes que devem fazer recurso aos tribunais que zelam pela manutenção das formalidades necessárias ao bom andamento da partida. Temos assim mais um elemento fundamental para entender essa nova governamentalidade: a questão do direito, entendido como "campo institucional do poder público e deslanche de uma economia cujo processo será regulado com base na concorrência”.

Foucault (2008b, p. 245-6) faz questão de enfatizar que não se trata apenas de análise discursiva, de mero prazer em fazer a história de discursos atuais, mas de um ideário que "afinal constitui a armadura da política alemã contemporânea”; "modelo alemão" que, por sua vez, "pôde se difundir, por um lado, na política econômica francesa contemporânea e, por outro lado, também num certo número de problemas, de teorias e de utopias liberais, tais como vemos se desenvolver nos Estados Unidos”.

No caso francês, a intertextualidade com o programa alemão se evidencia, segundo Foucault (2008b, p. 267-8), no explícito "parentesco" entres os textos de $\mathrm{Va}$ léry Giscard d'Estaing - ministro da economia e finanças de De Gaulle e Pompidou, Presidente da República a partir de 1974 - e Raymond Barre - ministro da economia e finanças de Giscard -, de um lado, e os textos de Röpke, Müller-Armack, etc., de outro. Há, no entanto, um significativo hiato temporal entre as duas experiências de governamentalidade neoliberal.

No imediato pós-guerra, diferente da Alemanha, onde a estabilidade dos preços era o principal objetivo e o resto (crescimento do PIB, equilíbrio da balança de pagamentos, redistribuição de renda, pleno emprego, política social) viria a reboque; na França o primordial era o "pleno emprego" e o "fornecimento dos bens sociais", política que, segundo Foucault (2008b, p. 270), apresentou "resultados positivos". Também De Gaulle manteve, "com toda uma série de atenuações de tipo liberal, o essencial desses objetivos que podemos chamar de objetivos dirigistas, desses procedimentos dirigistas, desses métodos dirigistas, desses procedimentos planificadores...”. É só ao longo da década de 1970 que começa a se colocar praticamente ${ }^{9}$, na França, “o problema da liquidação final desses objetivos e dessas formas de propriedade econômico -política. É nessa década”, continua Fou-

9. Lembremos que, do ponto de vista intelectual, o Colóquio Walter Lippmann, marco fundamental de gênese do neoliberalismo, aconteceu em Paris, agosto de 1938. 
cault $(2008 b ; 270)$, "que se coloca o problema da passagem global a uma economia neoliberal, isto é, grosso modo, o problema de alcançar e de inserir o modelo alemão”.

A partir de 1973 imputa-se o crescimento do desemprego e da "inversão do saldo credor da balança de pagamentos" a "uma crise no regime de investimentos", à irracionalidade das "opções de investimento". Junto a isso deflagra a crise do petróleo devido "à diminuição da influência econômica e política do cartel dos compradores e à constituição de um preço de mercado para o petróleo e, de modo mais geral, para a energia” (FOUCAULT, 2008b, p. 270-1), de modo que os compradores franceses se viram com baixo poder de barganha frente à padronização dos preços de mercado. 0 liberalismo, "a integração total, sem restrições, da economia francesa numa economia de mercado interna, europeia e mundial" aparece como $a$ alternativa contra os erros dirigistas - "para retificar os erros de investimento, por um lado, e para ajustar a economia francesa ao novo preço da energia” (FOUCAULT, 2008b, p. 271).

A prova maior, para Foucault (ver FOUCAULT, 2008b, p. 275-6), de que não se trata apenas de mais um momento da polarização intervencionismo/liberalização constituinte da história francesa, é a decisiva redefinição do significado da política social a partir de Giscard, quando a ampla Seguridade Social, defendida durante décadas após a II Guerra, passa a ser vista como negativa em suas consequências econômicas por aumentar o custo do trabalho. Esse aumento, por sua vez, num encadeamento perverso, prejudicaria a situação da indústria francesa em relação à concorrência internacional e diminuiria a absorção de novos trabalhadores, aumentando o desemprego e gerando distorções indesejadas na distribuição da renda.

É nesse pano de fundo de crítica à Seguridade Social, que imbrica negativamente o social ao econômico, que Giscard - Foucault (2008b, p. 276) remete a uma comunicação realizada num colóquio em 1972 - defende a maior possível separação entre os dois planos e mimetiza o discurso ordoliberal sobre o jogo econômico e a função do Estado nesse jogo: a "ideia de que a economia é um jogo, de que há regras de jogo da economia garantidas pelo Estado e de que o único ponto de contato entre o econômico e o social é a regra de salvaguarda que faz que nenhum jogador seja excluído dele” (Foucault, 2008b, p. 278); "a ideia de que deve haver uma regra de não-exclusão e de que a função da regra social, da regulamentação social, da Seguridade Social no sentido amplo do termo deve ser a de garantir pura e simplesmente a não-exclusão de um jogo econômico que, fora disso, deve desenrolar-se por si mesmo" (FOUCAULT, 2008b, p. 278-9).

Tal compreensão restrita da política social, em clara oposição à forma como ela era concebida pelos partidários da ampla Seguridade Social, ganha síntese na ideia de "imposto negativo", implementada a partir de 1974 por Giscard. Dizem os partidários do imposto negativo:

se se quer ter uma proteção social eficaz sem incidência negativa, há simplesmente que substituir todos esses financiamentos globais, todos esses subsídios mais ou menos categoriais, por um subsídio que seria em espécie e proporcionaria recursos suplementares a quem, e somente a quem, a título definitivo ou a título provisório, não alcança um patamar suficiente (FOUCAULT, 2008b, p. 280.

Nessa leitura, os benefícios da política social deixam de ser universalizados e de- 
vem se direcionar somente para aqueles que não têm condições de participar do jogo econômico (idosos e deficientes), que estão provisoriamente fora do jogo (desempregados) ou têm condições precárias de jogar (baixa renda). Tais benefícios devem ser acompanhados sempre de estímulos que motivem a entrada ou o maior envolvimento no jogo.

Fundamental reter (FOUCAULT, 2008b, p. 281-4) que o imposto negativo e os benefícios sociais derivados dele agem no nível dos efeitos e nunca das causas da pobreza, o que quer dizer: 1) em primeiro lugar, que se desfaz "a distinção que a governamentalidade ocidental procurou por tanto tempo estabelecer entre os bons pobres e os maus pobres, os que não trabalham voluntariamente e os que estão sem trabalho por razões involuntárias"; 2) que se evita "absolutamente tudo o que poderia ter, na política social, efeitos de redistribuição geral de renda, isto é, grosso modo, tudo o que poderia se colocar sob o signo da política socialista"; 3) que há uma "segurança geral" abaixo de certo limiar, acima deste "cada um deverá ser para si mesmo e para a sua família, de certo modo, uma empresa”, forma-se assim "uma espécie de população flutuante" na intersecção dos dois patamares, que constitui, "para uma economia que justamente renunciou ao objetivo do pleno emprego, uma perpétua reserva de mão-de -obra que se poderá utilizar, se necessário, mas se poderá mandar de volta ao seu estatuto de assistida, se necessário também”.

Há no discurso neoliberal francês, para Foucault (2008b, p. 2985), uma "radicalização desses temas gerais” presentes no ordoliberalismo alemão e na tendência majoritária do Colóquio Walter Lippmann. E, de fato, lá, como aqui, a mesma reorientação do Estado e da política social em favor da integração à economia de mercado, a mesma compreen- são da sociedade segundo o modelo do jogo concorrencial, a mesma generalização do modelo de empresa ao nível das subjetividades ou, numa outra formulação, a sujeição dos indivíduos ao modelo empresarial.

$\mathrm{Na}$ aula de 14 de março, Foucault (2008b) aborda o neoliberalismo americano que, a semelhança dos alemães e franceses, tem como principal oponente o dirigismo do Welfare State, nesse caso o New Deal de Roosevelt. Singular é, porém, a precedência de uma forte tradição liberal. "Foi a título de princípio fundador e legitimador do Estado que o liberalismo foi convocado" (FOUCAULT, 2008b, p. 300), e tanto a direita como setores da esquerda estadunidenses tendiam a simpatizar com argumentos liberais. É nesse contexto, portanto, que Hayek clama por "um liberalismo que seja um pensamento vivo".

Dois são os principais elementos enfatizados por Foucault (2008b, p. 302) em sua análise do neoliberalismo estadunidense: 1) "a teoria do capital humano"; 2) "o programa da análise da criminalidade e da delinquência”.

Parece-me ser possível afirmar que a teoria do capital humano representa uma radicalização daquilo que vimos nos neoliberais alemães e franceses como um poder enformador (Gesellschaftspolitik) da sociedade segundo a concorrência a tal ponto que as próprias subjetividades, sejam quais forem os seus fins, devem se conformar a um modelo empresarial. Assim, escreve Foucault (2008b, p. 302), trata-se da "possibilidade de reinterpretar em termos econômicos e em termos estritamente econômicos todo um campo que, até então, podia ser considerado, e era de fato considerado, não-econômico".

Essa nova abordagem dos fenômenos humanos tem seu fundamento teórico na 
reavaliação que os neoliberais americanos fazem da categoria trabalho na economia ${ }^{10}$. Trabalho abordado não sobre o seu preço, sobre o que "produz tecnicamente" ou sobre "o valor" que o tempo de trabalho "acrescenta" às mercadorias que produz, mas "análise do trabalho", escreve Foucault (2008b, p. 306-7) a partir de "como quem trabalha utiliza os recursos de que dispõe”, recursos que são considerados "raros", escassos, e alocados segundo "fins que são fins alternativos”. Trabalho não como objetividade ou objetivação, mas como subjetividade racional orientada por fins. "A economia já não é, portanto, a análise da lógica histórica do processo, é a análise da racionalidade interna, da programação estratégica da atividade dos indivíduos" (FOUCAULT, 2008b, p. 307).

Nessa abordagem do trabalho como conduta de quem trabalha - do "sujeito econômico ativo” (FOUCAULT, 2008b, p. 308) -, há uma oposição perfeita em relação à concepção do trabalho como atividade da "força de trabalho que deveria se vender a preço de mercado a um capital que seria investido numa empresa”. Aqui, o trabalhador é ele mesmo um capital, um "capital-competência, que recebe, em função de variáveis diversas, certa renda que é um salário, uma renda-salário, de sorte que é o próprio trabalhador que aparece como uma espécie de empresa para si mesmo".

Os trabalhadores não são considerados como indivíduos, mas como "unidades-empresas”. Eis o "princípio de decifração”, escreve Foucault (2008b, p. 310), do projeto teórico neoliberal estadunidense em seu programa "para a racionalização tanto de uma sociedade como de uma economia". Sim, afırma Foucault (2008b, p. 310-1), há um "retorno ao homo oeconomicus", mas enquanto o homo oeconomicus clássico "é o homem da troca, é o parceiro, é um dos parceiros no processo de troca" decomposto em termos de utilidade referida a certas "necessidades"; o sujeito imaginado pelo neoliberalismo "é um empresário, um empresário de si mesmo", "sendo ele próprio seu capital, sendo para si mesmo seu produtor, sendo para si mesmo a fonte de [sua] renda".

Trata-se, portanto, em todas as manifestações do neoliberalismo (alemã, francesa, estadunidense), "de desdobrar o modelo econômico, o modelo oferta e procura, o modelo investimento-custo-lucro" e fazer dele "um modelo das relações sociais, um modelo da existência, uma forma de relação do indivíduo consigo mesmo, com o tempo, com seu círculo, com o futuro, com o grupo, com a família" (FOUCAULT, 2008b, p. 332).

Talvez pelos diferentes contextos de tradição intelectual a partir dos quais se desenvolvem, Foucault (2008b, p. 332-4) percebe certas nuances ao comparar o neoliberalismo alemão e norte-americano. Os ordoliberais alemães defendem de forma ambígua aquela generalização do modelo da empresa para toda a sociedade e para a subjetividade ao lado de uma promessa de desalienação, onde a "economização de todo o campo social” é apresentada como “uma Vitalpolitik que terá por função com- 
pensar o que há de frio, de impassível, de calculista, de racional, de mecânico no jogo da concorrência propriamente dita" - numa estranha conciliação entre utilitarismo e romantismo. Nos neoliberais estadunidenses, por sua vez, essa ambiguidade desaparece, na medida em que a generalização do homo oeconomicus para formas monetárias e não-monetárias de relação social (ser empresário de si em todas as dimensões da vida) é em si percebido como uma utopia, como afırmação das liberdades.

Para Foucault (2008b), a generalização do homo oeconomicus para todos os níveis da vida representa, precisamente, mais do que um imperialismo epistêmico, o delineamento da novidade da arte de governar neoliberal. É só aqui que Foucault (2008b, p. 339-40) se vê com o instrumental necessário para abordar, em "artigos de Ehrlich, Stigler e Gary Becker”, sobretudo a obra Crime e Castigo do último, aquilo que prometeu na aula de 14 de março: o programa neoliberal de análise da criminalidade e da delinquência.

Trata-se de um caso exemplar - na medida em que o modelo de empresa é utilizado para a crítica do direito penal - do cruzamento entre "análise dos comportamentos não-econômicos através de uma grade de inteligibilidade economista" e a "crítica e avaliação da ação do poder público em termos de mercado". Para não nos alongarmos, pode-se dizer que os neoliberais estadunidenses operam uma "supressão antropológica do criminoso" (FOUCAULT, 2008b, p. 353), que passa a ser considerado estritamente em termos de homo oeconomicus.

Se tomarmos a definição ultraformalizada (sem conteúdo) de crime como aquilo “que é punido pela lei”, a definição neoliberal subjetiva tal formulação e toma o crime como "toda ação que faz um indiví- duo correr o risco de ser condenado a uma pena” (FOUCAULT, 2008b, p. 344-5). 0 crime é mais um recurso que pode ser utilizado como meio para atingir determinados fins, que se singulariza apenas pelo fato do sujeito correr "o risco de ser punido". "0 criminoso é todo mundo, quer dizer, ele é tratado como qualquer pessoa que investe numa ação, que espera lucrar com ela e aceita o risco de uma perda" (FOUCAULT, 2008b; 346). Deriva daí, escreve Foucault (2008b, p. 349-50), a função de uma "política penal" não de "supressão" ou "anulação exaustiva do crime”, mas de regular, de intervir "no mercado do crime e em relação à oferta do crime", intervenção tal que racionalize a limitação da "oferta do crime" sem superar "o custo dessa criminalidade cuja oferta se quer limitar".

Concebendo assim a criminalidade e o criminoso, Gary Becker vai além da generalização da análise econômica para toda conduta racional, proposta em Human Action de Von Mises, e percebe a possibilidade de estendê-la, inclusive, para condutas irracionais. É aí que Foucault percebe mais um elemento de distinção - junto ao contraste entre o parceiro da troca e o empresário de si - entre o homo oeconomicus do liberalismo clássico e do neoliberalismo.

O liberalismo e a economia política são saberes que constituem práticas de limitação dos diferentes domínios, das racionalidades (econômica, política, jurídica, etc.) heterogêneas, para que uma não ultrapasse o limite da outra.

0 neoliberalismo, em distinção, concebe a possibilidade: por um lado, em todas as suas versões, de um compromisso, de uma convergência, entre estas diferentes racionalidades segundo o interesse de constituição da economia de mercado; por outro lado, de forma ainda mais explícita em 
sua ancoragem norte-americana, de definir todas as outras racionalidades segundo o modelo da empresa. Em outras palavras, há tanto a orientação da racionalidade estatal, jurídica, institucional em geral, em função da constituição da economia de mercado, como a compreensão de outros fenômenos segundo o modelo do homo oeconomicus neoliberal, o capital humano.

0 neoliberalismo é uma utopia sobre a sociedade ideal (a economia de mercado) e um novo homem (o capital humano).

\section{Considerações finais: a gênese da intelec- tualidade neoliberal}

Não me parece, portanto, minimamente forçado abordar a origem e o desenvolvimento das práticas e discursos analisados por Foucault em Nascimento da Biopolitica como constituição de uma intelligentsia ou intelectualidade, dado que, embora delineie um quadro de pensamento com seus limites, não se trata de um conceito fechado e inflexível, como buscamos salientar na rápida sumarização das suas modulações na segunda metade do século XIX e durante o século $\mathrm{XX}$.

Em nossa leitura, salientamos, logo de partida, como a análise da governamentalidade liberal e neoliberal nos cursos dados por Foucault (2008a, 2008b) em 1978 e 1979, implica numa contribuição singular para pensar a formação intelectual. Para ele, tais racionalidades de governo particularizam-se e exprimem sua modernidade por serem enunciadas como regimes de verdade sobre a dinâmica populacional (com seus sujeitos constituintes) e por isso reivindicam uma influência central na gestão, dentro e fora do Estado, da sociedade. Contraste vivo com uma intelectualidade pré-moderna (razão de estado, mercantilis- mo) que, em sua posição interna ao próprio aparelho estatal, busca se fundar na finalidade tautológica de reprodução do próprio Estado ou, na expressão específica do filósofo francês, em regimes jurisdicionais.

Assim, a intelectualidade moderna que interessa a Foucault nesse momento da sua obra se refere a uma rede de enunciados e sujeitos de enunciação que buscam delinear um saber científico, verdadeiro, para o governo das coisas e dos seres humanos.

Revisitamos, em sequência, a genealogia foucauldiana da governamentalidade neoliberal, que: começa com uma análise da composição do Conselho Científico em 1947, junto à administração alemã da economia, com forte presença da Escola de Friburgo (W. Eucken, F. Böhm, Müller-Armack, L. Miksch, A. Lampe, O. Veit); analisa o discurso em Frankfurt de Ludwig Erhard em 1948, baseado em relatório do mesmo ano elaborado pelo Conselho Científico; analisa a difusão prática das ideias (neo)liberalizantes desse grupo na década de 1950 na Alemanha, definindo o chamado modelo alemão; retorna aos fundamentos teóricos dessas práticas e discursos a partir da fundação da revista Ordo (por isso ordoliberais) em 1936, também formada por membros daquele Conselho (Böhm, Müller-Armack) e outros como Rüstow, Hayek; analisa outro evento fundamental que é o Colóquio Walter Lippmann, realizado em 1938, quando se forma a Comissão Internacional de Estudo para a Renovação do Liberalismo, onde se encontravam o próprio Lippmann, Louis Rougier, Röpke, Rüstow, Hayek, von Mises, entre outros; analisa textos centrais de Eucken (que não participou do Colóquio mencionado por proibição do governo Nazista para sair da Alemanha), assim como de Röpke, Rougier e, mais à frente, Hayek; sai do caso alemão e analisa o desenvolvi- 
mento do neoliberalismo na França a partir da década de 1970, nas práticas e discursos de Valéry Giscard d'Estaing, Raymond Barre, e suas afınidades com o ordoliberalismo; até, por fım, analisar a radicalização do neoliberalismo nos EUA, sobretudo em textos da Gary Becker.

Embora a revista Ordo surja em 1936, nos parece correto afirmar o Colóquio Walter Lippmann, realizado dois anos depois, como um marco ainda mais importante na gênese da intelectualidade neoliberal, como o faz o próprio Foucault e é apoiado, recentemente, por Dardot e Laval (2016, p.72), que veem a famosa Sociedade Mont Pèlerin (criada em 1947 por Hayek, Popper, von Mises, Friedman, entre outros) "como um prolongamento da iniciativa de 1938”, esta sendo indiscutivelmente "a primeira tentativa de criação de uma 'internacional' neoliberal que se prolongou em outros organismos, entre os quais, nas últimas décadas, a Comissão Trilateral e o Fórum Econômico de Davos".

Jurgen Reinhoudt e Serge Audier (2018) buscam, em certa medida mitigando a ênfase dada por Dardot e Laval (2016), explicitar continuamente as diferenças entre, de um lado, a posição mais dirigista em nome da economia de mercado dos ordoliberais (Rüstow, Röpke), Lippmann, Rougier e, de outro lado, a posição mais próxima ao laissez-faire clássico ou manchesteriano de Von Mises, Rueff, Hayek. Diferenças de posição que serão claramente demarcadas na passagem de uma liderança germano-francesa no Colóquio Walter Lippmann para uma liderança austro-americana (incluindo decisivamente Milton Friedman e os Chicago boys) na Sociedade Mont Pèlerin onze anos depois.

No entanto, a demarcação de tais diferenças não impede Reinhoudt e Audier
(2018, p. 5-6) de afirmarem que o Colóquio "marca o local de nascimento formal do neoliberalismo como um movimento intelectual"; que, como "um conjunto de ideias, mas também como uma rede intelectual e doutrinal”, o “'neoliberalismo' nasceu formalmente cristalizado - em um Colóquio realizado entre 26 e 30 de agosto de 1938 em Paris”. 0 que não implica afırmar, continuam os autores, "que não existissem ideias ou argumentos 'neoliberais' antes daquela época”, mas que, "como um movimento intelectual, em 1938 o neoliberalismo adquiriu um grau de coesão... que até então faltava, assim como um nome oficial", mesmo com as disputas e a "profunda heterogeneidade interna".

Em sua história anterior ao Colóquio, conforme Reinhoudt e Audier (2018, p. 7), o termo "neoliberalismo" foi utilizado pela primeira vez por um político da direita conservadora francesa, Pirre-Étienne Flandin. Depois por Gaëtan Pirou, em 1934, e por Marcel Déat, em 1937, de modo pejorativo numa crítica a Léon Blum. Louis Rougier, que após ler The Good Society de Walter Lippmann propõe e organiza o Colóquio de 1938, escreveu, no convite para o mesmo, sobre a necessidade de uma articulação programática visando a constituição não de um "neoliberalismo", mas de um "liberalismo positivo" ou "liberalismo construtor", em claro contraste com o que seria o liberalismo do laissez-faire machesteriano. Durante o Colóquio, porém, acata a sugestão de Rüstow de adotar “'neo-liberalismo'... como título para um liberalismo econômico e político renovado e revigorado" (REINHOUDT; AUDIER, 2018, p. 25).

Eis, portanto, uma primeira importância decisiva do Colóquio Walter Lippmann: é a primeira vez que "neoliberalismo" aparece não apenas como um termo difuso, mas 
para conotar uma rede internacional, mais ou menos coesa, de intelectuais e discursos política e teoricamente interessados.

Tal unificação ou convergência formal, obviamente, não desfaz significativas diferenças internas, advindas da própria origem social, profissional e política dos seus atores constituintes. Em sua maioria economistas (os franceses Louis Baudin, Jacques Reuff, Bernard Lavergne, André Piatier, Étienne Mantoux, Robert Marjolin, os ordoliberais alemães Wilhelm Röpke e Alexander Rüstow, Von Mises e Hayek como "lideranças da escola austríaca”, o polonês Michael Heilperin junto com John Bell Condliffe, “educados no Reino Unido"), mas também filósofos (Louis Rougier, Raymond Aron, Michael Polanyi), cientistas sociais (Bruce Hooper, Alfred Schütz), servidores civis (Roger Auboin, Marcel van Zeeland), “empresários de sucesso, lideranças industriais e tecnocratas (Marcel Bourgeois, Auguste Detoeuf, Louis Marlio, Ernest Mercier), um jurista espanhol (José Castillejo), e, é claro, um jornalista (Walter Lippmann)” (REINHOUDT; AUDIER, 2018, p. 11).

A despeito de tal heterogeneidade, sobressai como unidade, em forte acordo com aquela sintética defınição da intelligentsia proposta por Martins (1987), em primeiro lugar, uma acentuada autorrepresentação desses intelectuais como isolados, ilhados num oceano de defesas do intervencionismo estatal em todos os âmbitos da socieda- de, isolamento este catalisado por uma estereotipação do campo inimigo não liberal como, senão defınitivamente, tendencialmente totalitário ${ }^{11}$. Deriva deste isolamento aquela "visibilidade devida mais à posição única dos seus membros do que propriamente à sua constituição em stratum social, condição esta, aliás, incompatível com seu número excessivamente restrito". Tornamse visíveis pelo seu programa ou projeto político-intelectual e não por sua quantidade ou posição definida na estrutura social.

Em segundo lugar, tal operação de identificação entre intervencionismo ou planismo e totalitarismo é a base negativa para a proposição de uma nova utopia da economia de mercado. Assim, realiza-se aquela conversão da impotência imposta pelo isolamento em um "sentimento de missão", neste caso de fundamento não somente ético, mas que também se pretende científico, verdadeiro. Talvez seja mais preciso afirmar, recuperando o raciocínio ordo, que, em contraste com o liberalismo e a sua concepção naturalista da autorregulação do mercado, o fenomenalismo neoliberal de fato elabora uma utopia da economia de mercado enquanto forma ideal de organização da sociedade a ser paulatinamente construída por meios de ativismo político, jurídico, institucional. Em tal utopia não se trata apenas de não intervir no mercado, mas de construir uma sociedade inteiramente baseada no modelo da concorrência

11 "In this way, one already sees three themes emerge from the Walter Lippmann Colloquium through these invitees: the threat of totalitarian systems that were supported by the masses, the threat of war combined with the economic policies of autarky, and finally the need to more or less revise liberalism in response to the revolt of the masses" (REINHOUDT; AUDIER, 2018, p. 14). 
e na construção de um homem novo, o empresário de si.

Em terceiro lugar, tal programa político -intelectual não define apenas uma relação ambivalente com o Estado, mas uma oposição radical à forma como se concebe a ação e a intervenção estatal em formas não liberais e a proposição de um Estado (e de um direito) que seja inteiramente regulado pela economia de mercado e os fins do mecanismo de concorrência ${ }^{12}$.

Em quarto e último lugar, se no texto foi menos explícita a "autoatribuição" por parte dessa intelectualidade neoliberal como representantes da nação, do povo, da população não-esclarecida; em todos esses discursos há tanto uma rejeição ao intervencionismo estatal planificador como a defesa do mecanismo da concorrência como a condição principal para a garantia da liberdade dos indivíduos, assim como a ideia de que o crescimento permitido pela economia de mercado seria produtor espontâneo de bem-estar social. Como escreve Hayek (2010, p. 9) no seu prefácio da edição inglesa já mencionada d'O caminho da servidão: "Não consigo descobrir uma razão para que o tipo de sociedade que me parece desejável deva oferecer maiores vantagens a mim do que à grande maioria do povo deste país".

Em relação às concepções que concebem, a partir da experiência russa e francesa, a intelligentsia e os intelectuais, sobretudo como grupos progressistas ou que se colocariam à esquerda em relação à conjuntura política em que se inserem, vimos como Gramsci já nos ensina que os intelectuais podem ser orgânicos não apenas em relação aos subalternos, representando-os e liderando-os simbolicamente, mas também em relação às camadas sociais interessadas em reproduzir padrões de exploração e dominação do ser humano pelo ser humano.

A genealogia foucauldiana não permite afirmar que o programa político-intelectual ordo e neoliberal desde os seus princípios foi orientado como sistematização da visão de mundo e instrumento simbólico das classes dominantes. Encontramos em seus componentes importantes tecnocratas, homens de negócios e industriais. Entre estes, Marcel Bourgeois (REINHOUDT; AUDIER, 2018, p. 38), localizado à direita no espectro político francês, suporte financeiro

12. "At its founding in August 1938, neo-liberalism consisted of support for two main arguments. First, Colloquium participants supported economic and political liberalism, and opposed centrally directed systems (first and foremost communism, National Socialism, and fascism, but also the more democratic forms that derived inspiration, according to them, from these systems). Second, participants supported the market pricing mechanism as an allocator of resources in all areas of the economy. The Colloquium also reveals that as a set of ideas, neo-liberalism in 1938 was opposed neither to State intervention in the economy nor - for a participant such as Rüstow, but also for Rougier - to a 'strong state' that would ensure the survival of the market order" (REINHOUDT; AUDIER, 2018, p. 18-9). Obviamente, a forma como tal intervenção ou dirigismo estatal em favor da economia de mercado deveria se dar contemplava as mais diversas opiniões. Entre os extremos, segundo Reinhoudt e Audier (2018), há aqueles que preservavam alguma proximidade crítica a Keynes e os keynesianos (Lippmann, Marlio, Aron, Marjolin, Condliffe, Polanyi) e aqueles que rejeitavam radicalmente o keynesianismo (Mises, Hayek, Rueff, Mantoux e em certo grau Röpke). No entanto, todos compartilhavam a ideia de que, do ponto de vista econômico, qualquer orientação político-jurídica deveria buscar otimizar o supramencionado "market pricing mechanism". 
fundamental da editora Médicis, de clara “inclinação conservadora” (REINHOUDT; AUDIER, 2018, p. 8) e principal casa de publicação das obras neoliberais, a começar por The Good Society, de Lippmann, traduzido como La cité libre. Informações que não anulam a heterogeneidade de posições políticas.

Reinhoudt e Audier (2018, p. 20) chegam mesmo a afirmar que o "neoliberalismo inicial era explicitamente, pelo menos em muitos casos, antirreacionário e se opunha, em geral, a sistemas herdados de classificação...", posição demarcada por figuras como Aron, Lavergne e M. Polanyi, defensores convictos da democracia liberal. Não faltavam, no entanto, participantes que flertavam com posturas autoritárias, como: Louis Baudin, que admirava Salazar; Von Mises, apoiador do Chanceler Engelbert Dolfuss, "que havia esmagado o movimento trabalhista" austríaco, o mesmo Von Mises que, apesar de ter sido vítima de antissemitismo e das suas críticas ao fascismo, elogiava as investidas deste contra o bolchevismo; ou Louis Rougier, que apoiou Pétain, mas passou ulteriormente a se localizar "no campo da modernidade pluralista, liberal e democrática, no sentido da democracia parlamentar e constitucional" (REINHOUDT; AUDIER, 2018, p. 21).

Se de tendência mais democrática ou mais autoritária, parece difícil, e mesmo infrutífero, dada a sua composição heterogênea, definir uma essência político-normativa da intelectualidade neoliberal em suas origens. Não parece haver dúvida, no entanto, que a implementação destas ideias, mais ou menos fiel às suas formulações genéticas, converteu, praticamente, a utopia da liberdade e do bem-estar através da busca de uma economia de mercado perfeita, em distopia: exacerbação das desi- gualdades sociais e supressão de conquistas democráticas em todo o globo. No entanto, reiteramos: isto em nada tira o seu caráter de intelectualidade (no sentido gramsciano) que, a despeito das evidências desastrosas das (des)regulamentações em favor do mercado, continua a ser central, amparada em discurso que se pretende universalista e científico, no governo do mundo.

\section{Referências}

BRÖCKLING, U.; KRASSMAN, S.; LEMKE, T. From Foucault's lectures at the Collège de France to studies of governmentality: an introduction. In: BRÖCKLING, U.; KRASSMAN, S.; LEMKE, T. Governmentality: current issues and future challenges. New York: Routledge, 2011.

BROWN, W. Undoing the Demos: Neoliberalism's Stealth Revolution. New York: Zone Books, 2015.

DARDOT, P.; LAVAL, C.. A Nova Razão do Mundo. São Paulo: Boitempo, 2016.

FOUCAULT, M. Segurança, território, população: curso dado no Collège de France (1977-1978). São Paulo: Martins Fontes, 2008a.

\section{Nascimento da biopo-}

lítica: curso dado no Collège de France (19781979). São Paulo: Martins Fontes, 2008b.

GORDON, C. Chapter One. Governmentality rationality: an introduction. In: BURCHELL, G. GORDON, C. MILLER, P. The Foucault effect: studies in governmentality. Chicago: The Univerisity of Chicago Press, 1991.

GRAMSCI, A. Os intelectuais e a organização da cultura. Rio de Janeiro: Civilização Brasileira, 1968.

HAYEK, F. O caminho da servidão. São Paulo: Instituto Ludwig von Mises Brasil, 2010.

KOLEV, S. F. A. Hayek as an ordo-liberal. In: HWWI Research Paper, No. 5-11, 2010.

LAGASNERIE, G. de. La última lección de Michel 
Foucault: Sobre el neoliberalismo, la teoría y la política. Ciudad Autónoma de Buenos Aires: Fondo de Cultura Económica, 201

MANNHEIM, K. 0 problema da "intelligentsia": um estudo de seu papel no passado e no presente. In: MANNHEIM, K. Sociologia da cultura. São Paulo:

Perspectiva, 2001.

MARTINS, L. A gênese de uma intelligentsia; os intelectuais e a política no Brasil, 1920-1940. Revista Brasileira de Ciências Sociais, v. 2, n 4 , p. 65-87, 1987.

PASSIANI, E. Figuras do intelectual: gênese e devir. Sociologias, Porto Alegre, ano 20, n. 47, pp. 16-47, jan./abr. 2018.

REINHOUDT, J. ; AUDIER, S. The Walter Lippmann Colloquium: the birth of neo-liberalism. Basinstoke: Palgrave Macmillan, 2018.

SILVA, L. T. da. Biopolítica e o enunciado da autonomização das esferas sociais. 2018. 328 f., il. Tese (Doutorado em Sociologia)-Universidade de Brasília, Brasília, 2018. Disponivel em: http:// repositorio.unb.br/handle/10482/32140

VIEIRA, C. E. Intelligentsia e intelectuais: sentidos, conceitos e possibilidades para a história intelectual. Revista brasileira de história da educação, $\mathrm{n}$. 16, pp. 63-85, jan./abr. 2008. 
RESUMO

Após uma sumária revisão de algumas abordagens sobre a origem e o conceito de intelligentsia e intelectuais, este artigo busca demonstrar rapidamente, num primeiro momento, como Foucault concebe a racionalidade de governo moderna, a partir dos fisiocratas e da economia política, como corpo sistematizador de práticas e discursos de poder fundados em regimes de verdade, em contraste com uma arte de governar prémoderna (mercantilismo, razão de Estado) ainda embaraçada com a afırmação do poder como regime de justiça. Num segundo momento, leremos o Nascimento da Biopolítica como uma detida análise da formação prático-discursiva de um novo regime de verdade no ordoliberalismo alemão e no neoliberalismo francês e estadunidense. Ao fim, reiteramos, em diálogo com a primeira parte do artigo, a razoabilidade de falarmos em uma intelectualidade ordo e neoliberal a partir dos estudos de Foucault.

\section{PALAVRAS-CHAVE}

Intelligentsia. Intelectuais. Governamentalidade. Neoliberalismo.

\section{ABSTRACT}

After a brief review of some approaches to the origin and concept of intelligentsia and intellectuals, this article seeks to demonstrate, at a first moment, how Foucault conceives the modern rationality of government from the physiocrats and political economy as a systematizing body of practices and discourses of power based on regimes of truth, in contrast to a pre-modern art of governance (mercantilism, reason of state) still embarrassed with the assertion of power as a regime of justice. In a second moment, we will read The Birth of Biopolitics as a detained analysis of the practicaldiscursive formation of a new regime of truth in German ordoliberalism and French and American neoliberalism. Finally, we reiterate, in dialogue with the first part of the article, the reasonableness of speaking in an ordo and neoliberal intelligentsia based on Foucault's studies.

\section{KEYWORDS}

Intelligentsia. Intellectuals. Governmentality. Neoliberalism. 